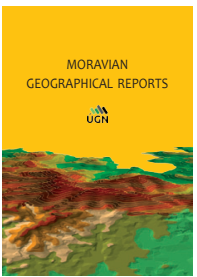

MORAVIAN GEOGRAPHICAL REPORTS

The Czech Academy of Sciences, Institute of Geonics

journal homepage: http:/www.geonika.cz/mgr.html

doi: https://oi.org/10.2478/mgr-2021-0011

\title{
Vulnerable Roma communities in times of the Covid-19 negative quarantine
}

\author{
Cătălin BERESCU ${ }^{\text {a }}$, Filip ALEXANDRESCU ${ }^{\mathrm{a}}$, Ionuţ Marian ANGHEL ${ }^{\text {* }}$
}

\begin{abstract}
In contrast to other countries in East Central Europe, Romania stands out because of a high number of small and segregated Roma settlements. As an ethnic minority, the Roma are overrepresented in marginalised and impoverished settlements and, given the basic recommendations to contain the pandemic - wash hands, keep the distance and work from home, their situation was disproportionately exacerbated by the imposition of lockdown measures. We use secondary data to interpret the deprivation features that puts them at greater epidemic risk. In addition, the Covid-19 crisis led to a sudden return of the Romanian Roma living in Western Europe. The slums and ghettos were more strictly quarantined than regular areas, suggesting a form of negative quarantine. Quarantine was - next to its medical purpose - used as a rhetoric and disciplinary device. Roma were portrayed as infection spreaders, and racism was channelled mainly through the media. While the spread of the disease placed them at risk, the lockdown itself induced major survival challenges. By using media and social media analysis, we show how the discourse of negative quarantine unfolded. The latter was diluted in the general relaxation of containment measures, but its legacy as a practice raises questions for the future governance of areas inhabited by the Roma.
\end{abstract}

Keywords: Roma, ghetto, Covid-19, negative quarantine, racism, Romania

Article history: Received 25 October 2020, Accepted 15 June 2021, Published 30 June 2021

\section{Introduction}

In a Facebook post entitled "An unsafe Romania" and dated April 22, 2020, five weeks after the beginning of the lockdown in Romania, the former mayor of Târgu Mureş, a mid-sized Transylvanian city, wrote that he felt rage against the feebleness of police forces who "simply watch as certain social categories refuse to obey the measures against the spread of the coronavirus". In a previous post, entitled "The birth of a child should be a great responsibility in a civilised state", he clarified which "social categories" he had in mind: "the Gypsies are a serious problem for Romania", especially those that "come from socially deprived areas, which are completely out of control". In a few short sentences the mayor, who had already been fined before by The National Council for Combating Discrimination (NCCD), portrayed the Roma settlements as hotbeds of the spread of SarsCov-2, even before the first case of Covid-19 was recorded in Romania and two months before the state of emergency was declared.

The return of the Roma migrants proved to be as equally troublesome as their "irregular" mobility towards the West (Anghel, 2019), not just in Romania, but also in other Central and Eastern European countries (e.g. Slovakia and Bulgaria). During the first four months of the pandemic, the Roma have repeatedly been constructed as vectors of spreading the disease among the majority population. Special measures to contain mostly larger Roma neighbourhoods were taken in Romania and Bulgaria, where entire streets were patrolled by police cars and special checkpoints, or makeshift walls were installed in order to prevent people from leaving (Bulgarian Institute for Legal Initiatives, 2020, EURACTIV, 2020b). A senior member of a coalition government party in Bulgaria has urged the government to "close the ghettos everywhere", while the Interior Minister justified the additional measures because: "we are obliged to protect the rest of the population" (Krasimirov and Tsolova, 2020). In Romania, several Roma neighbourhoods were quarantined and patrolled by police and military forces after some residents tested positive.

Slovakia's Prime Minister, Igor Matovič, announced at the beginning of April 2020 that the government will mobilise its military doctors, backed by the army, to test 33 Roma settlements with nearly 1,500 individuals who have recently returned from abroad. The measure was justified by government experts to contain a possible spread of the

\footnotetext{
${ }^{a}$ Research Institute for Quality of Life, Romanian Academy of Science, Bucharest, Romania (*corresponding author: I. M. Anghel, e-mail: ionut.anghel@iccv.ro)
} 
coronavirus, because of the "poor hygienic standards" (Virostkova, 2020). Moreover, the mayor of Košice stated bluntly that the Roma can spread the coronavirus because they are "socially unadaptable people", and thus accused of being less inclined to follow preventive measures (Tudor, 2020). Meanwhile, five Roma settlements from Eastern Slovakia, with around 6,000 people were quarantined and patrolled by police, although the then-current legislation upheld a $10 \%$ threshold for introducing a quarantine (Gabrizova, 2020). This political framing of the Roma resulted in intimidation, police brutality and sometimes in the strict quarantining of "Roma colonies" or ghettos.

Our paper addresses the imposition and logic of quarantining to show how the application of the prevailing measures of fighting Covid-19, namely - quarantining, physical distancing and curfew, with a disproportionate use of penal means, policing and discursive disciplinary devices created the premises for a dual system of control. This dual system supervises the majority society relatively loosely while concentrating its resources towards the policing of precarious Roma ghettos.

We observed a rational adaptation of most citizens to the constraints of the lockdown, which we term "neutral" quarantine. But on the other hand, we observed a "negative"quarantine that instituted a supplementary layer of surveillance in segregated Roma ghettos. The latter has a dialectical pair in terms of a "positive" quarantine, a cultural construct of the middle class, which identifies itself as the bearer of "civilisation" and fights for the "salvation" of various public goods and values. Due to an incessant dynamic and to the slightly different nature of the categories employed in the analysis, the neutral was a state-sanctioned form of governance, while the positive and negative were mostly a set of attitudes and practices that reinforce each other, suggesting emerging forms of governance, albeit we are aware that the three forms occasionally overlap. We engaged in a comparison of negative and neutral/positive quarantine, to highlight their interrelated forms but also their consequential outcomes.

Negative quarantine overlapped with the general measures taken during the lockdown but differed in the fact that it embedded a reactivation and intensification of preexisting racial tropes and forms of institutional control. The administrative practices of quarantining applied to Roma areas were thus likely to yield different results than those applied to the rest of the population. The ultimate aim was not the re-establishment of normalcy but the further control of a minority and of the area it inhabited on account of what appeared to be places of a new biological threat. Negative quarantine consisted at this stage of the flows of discourses, images, policies and spatial containment practices that went beyond medical interventions and were used to discipline the quarantined ethnic populations, along racialized lines. Those policies were forged in long-established practices of racialisation (Teodorescu, 2019; Vincze et al., 2019) that included evictions, administrative abandonment of settlements and discriminatory access to health, education and housing (Arpagian and Aitken, 2018). What was left unexplored in the Roma related literature was the sudden and radical deployment of a racially-charged discourse in an unprecedented medical-cum-economic crisis. We therefore ask how did the imposition of a (negative) quarantine affect the segregated Roma communities during the lockdown? At the outset, many Roma who did informal work in recycling, day labouring in agricultural activities, or other jobs on the grey or black market or seasonal migration, saw their meagre opportunities dwindling, leaving them with less to no income. In addition, in households with children attending pre-school or compulsory education, many children lost their only adequate daily meal.

Given these circumstances, our paper is structured around four objectives. First, we analyse the pre-existing conditions found in Roma segregated settlements before the onset of the pandemic. Second, we explore the securitisation challenges posed by the sudden return of some Roma to Romania and their discursive overtones. The third objective addresses the media representations related to Roma mobility during the state of emergency. The fourth objective is meant to advance and theorise the concept of negative quarantine as a way to draw attention to the implications of quarantining measures that are adopted in a racially charged socio-economic environment. Each objective will be addressed, in turn, in the four results subsections.

This article starts by presenting the theoretical background against which the negative quarantine concept is built. Next, we introduce the secondary and qualitative data on which we forged our analysis of some media-reflected conflicts surrounding the imposition of quarantining measures in several Romanian towns. The following two sections describe the sudden return of the Roma from Western Europe, including the challenges with which the health and local authorities were faced and the subsequent process of "making ethnic" the quarantined areas. The next section compares the features of the negative quarantine, enforced on some Roma ghettos, and the neutral quarantine applied to the rest of the population. We conclude by showing that many Roma communities have been on the losing side of quarantining policies, in particular those that relied on informal work or on work abroad. The implications of negative quarantine are nevertheless open ended and aggravating since they reverse the logic of protecting public health into a logic of social punishment in segregated areas.

\section{Theoretical background: \\ Securitisation, transnational mobility, and the threefold logic of quarantine}

The EU's "big bang" enlargement over a decade and a half ago has been considered a "security moment" (Goldstein, 2010, p. 487) regarding Roma mobility towards Western Europe. As many scholars have already argued (Balch, Balabanova and Trandafoiu, 2014; Hepworth, 2012; Sardelić, 2017), processes and practices of securitisation, "nomadisation" and criminalisation have characterised Roma westward mobility since 2004-2007 and have also legitimated contestable measures of dismantling Roma camps.

The EU-extension eastwards posed a large - yet anticipated - migration concern of impoverished Eastern Europeans towards the West. As a result, EU member states targetted this pauperised group (consisting disproportionately of Roma) with various securitisation techniques that are normally intended for non-EU migrants (van Baar, 2014). Within the ongoing process of securitisation of CEE Roma in the West, we theorise the securitisation of the opposite movement - of their return as potential "infectious super-spreaders" (van Baar, Ivasiuc and Kreide, 2019; Vrăbiescu, 2020).The restrictions of movement imposed by the Covid-19 pandemic in early 2020 have reactivated concerns with the excessive mobility of the Roma (Creţan and Light, 2020), this time articulated as 
prejudice against the infectious Other. This took the form of two interrelated processes that were thrust into prominence between March and May 2020. First was the swift reaction to the return of Roma migrants from Western Europe, which took the form of a crackdown against "undisciplined Roma" and the rapid imposition of local quarantines throughout Central and Eastern Europe (CEE). This created a new layer of hardships for segregated Roma groups, who used open spaces and connections to places beyond the ghetto to secure their survival (Málovics et al., 2019). The second process made visible the deeper logic of the early crackdown. The imposed quarantine was not meant as a temporary measure to protect all citizens against the spread of Covid-19 but rather as a one-sided device, similar to the cordon sanitaires in French-dominated Rabat (Picker, 2017). In other words, the quarantine was an attempt to "gut the ghetto". To summarise, the pandemic has been used by national authorities in CEE to temporarily raise the securitisation bar to a new level by introducing the negative quarantine as a form of bio-securitisation.

In its current meaning, the quarantine has a limited term during which the mobility and exchange of goods or services of an individual or group is restricted to prevent the spreading of a disease. Its practice has to comply with the general human rights framework and can only be limited in time. Baldacchino (2021, p. 1), however, argues that: "today, as in the past, these practices operate [in terms of] race, gender and citizenship, shielding some while exposing others to risk and even death". On the other hand, Simpson (2021) pinpoints to an emerging "prefigurative pandemic politics", which produces a racial colonial quarantine. Reflecting this background, we advance a theoretical distinction between positive, neutral, and negative quarantine regimes. In this article, we build on the streams of literature presented above by conceptualising the negative quarantine. This form refers, as we argue here, to a set of attitudes and policies that converge into the idea that the state should, under exceptional circumstances, exceed the legal framework and instantiate a form of ethno-racial control over Roma settlements.

The term "negative quarantine" is used here to describe the racialisation of the epidemic, to observe the changes in the governance of the ghetto and to reveal its institutional nature. Negative quarantine enables a distinct spatialisation of racism. It is the more or less arbitrary imposition of a state of quarantine without concern for the ability of the locked-up community and its members to actually survive during this time. The negative quarantine is not finalised by a restoration of normalcy but by a more or less harsh accentuation of extreme conditions that existed before the quarantine. It makes visible the outer shell of the community and makes invisible the innards of the quarantined place since the problem of their survival becomes one of individual struggle. Extending Wacquant's (2012) account of the institutional nature of the ghetto, the negative quarantine is thus a process that lays bare the relationships between a state that uses the pandemic to reinforce marginality and a racialised group whose vulnerabilities are exploited in a crisis situation.

While at the very beginning of the Covid-19 pandemic, the virus likely spread with comparable speed in Roma and nonRoma communities, it is only that the former were subject to over-policing, and the breaking of quarantining rules resulted in heavy punishment and large fines. The "ethnicisation of the pandemic" (Berta, 2020; Costache, 2020) was based on and reinforced by the racist tropes that portray the Roma as a gregarious, indivisible community, undisciplined and potentially violent. A "negative quarantine" is thus a way to keep under control a group that appears to exhibit unacceptable behaviours. Its counterpart, the "positive quarantine", is manifested through a display of willpower of a moral subject unaware of its privilege and proud of his or her capacity for self-discipline. Both attitudes gravitate around the "neutral quarantine", a rational and legal form of medical practice, adding to it some values and attitudes that eventually lead to further discriminatory actions.

The discussion so far has furnished the essential conceptual elements for the negative quarantine concept. In what follows, we assemble some observational basis for this concept, drawing on diverse sources of media information and secondary data.

\section{Methodology and data}

With the spread of the coronavirus to CEE, a state of emergency was declared by the governments to tackle and contain the spread of the virus. The lockdown started in Romania on the $16^{\text {th }}$ of March and ended on the $15^{\text {th }}$ of May, followed by an uninterrupted state of alert in which most of the stricter measures of isolation were lifted. For our research we used both quantitative and qualitative data (Berescu, 2010; Horváth, 2017; IRES, 2020) in order to better grasp:

a. The structural conditions that hamper Roma to better cope with the spread of the coronavirus, such as poverty, lack of space, lack of access to public utilities in the households, and overcrowding; and

b. The portrayal of negative quarantine in mass media and social media.

We use both hetero- (identified by others as "Roma") and self-ascribed ethnic identification from recent policydriven research. The methodological difficulties of using a certain type of identification is described by scholars such as Messing (2014) and Surdu (2016) that showed that Roma ethnicity may have different meanings in different socio-economic and political contexts. Our aim was to relate the data gathered through the media survey with the monitoring of social media, and the secondary data from recent quantitative studies on the quality of life in segregated Roma ghettos.

For the structural conditions of segregated communities, we used the SocioRoMap (2014-2017) database, the most recent major research on compact Roma communities in Romania. The database contains, among other elements, information on the number of households in segregated areas, their sources of income, access to public utilities and living conditions (e.g. overcrowding). As will be shown in the next section, the segregated Roma were ill equipped to cope with the medical and economic consequences of the coronavirus outbreak.

On the other hand, we use discourse analysis from mainstream news platforms and newspapers as well as pieces of information from Roma related platforms (RomLink and Aresel) and social media, to define the practice of negative quarantine during the state of emergency. We also scrutinised the mainstream newspapers and news platforms for information on the most visible cases of quarantined Roma ghettos, in order to interrogate the discursive mechanisms and practices through which negative quarantine was imposed and normalised. 
We selected our mass media articles and social media posts as follows. We monitored the national news online platforms: Hotnews, G4media, Mediafax and Agerpres between 15 March and 15 May 2020. We identified the articles and news items using combinations of keywords such as "Roma", "Covid-19", "quarantine", "Roma scandals", "ghetto" or "colonie" (Romanian word for segregated Roma settlement). We collected 163 media and social media items, reporting on 30 Roma-inhabited places from Romania, of which 14 are shown in Figure 1. Media arguments often have an ideological overreach that suggest that the quarantining of the Roma neighbourhoods should go beyond the medical interventions and serve rather as a disciplinary mechanism to govern the "uncivilised" and "undisciplined" Roma. The titles from national and local news platforms were translated into English and referenced only in the body of the article.

We complemented our information from media news platforms with social media posts from the Facebook page RomLink, one of the most active Roma social media pages, whose goal is "to inform about Roma issues and support networking between Roma activists and employees in public administration and state institutions working to improve the situation of Roma, combat racism and discrimination and promote respect of human rights" (RomLink, 2021). The page hosted many posts related to the quarantine conditions and illustrations of the over-policing that took place in several segregated settlements.

\section{Results and discussion}

Our findings have been grouped under four main headings. The first subsection provides secondary data from a recent research project on Roma from Romania. The subsection outlines the conditions that affected Roma ghettos before the pandemic, which made their coping with the Covid-19 effects even more difficult than for the rest of the population. The second subsection reveals the discursive response to the sudden return of the Roma from Western Europe to Romania.
It highlights the racialised underpinnings of this discourse relayed by political and opinion leaders in the media. The third subsection pays attention to the ways in which Romanian media have portrayed the lockdown through an ethnic frame. The final part of the findings broaches the key features of the newly minted concept of negative quarantine as a form of governance. This is characterised by a set of framings and practices that guard society against the threat posed by the "infectious Other" through over-policing of the quarantined areas and regulation of movement. All these went beyond medical interventions and were used to discipline the quarantined ethnic population, along racialised lines.

\subsection{Data on pre-existing conditions in Roma ghettos in Romania}

The state of emergency and the self-isolation measures in spring 2020 have likely deepened the poverty in ghetto settlements, since many inhabitants worked in low paid jobs that depended on contacts with other people or were involved in the recycling industry or collecting scrap materials (Cace et al., 2010). The "at risk of poverty" rate for Roma reaches $80 \%$, while one quarter of the persons live in households where at least one person had to go to bed hungry at least once a month (FRA, 2018). While the health experts recommended physical distancing, strict personal hygiene and the protection of vulnerable categories, this is hardly possible in many settlements, where overcrowding, living in multigenerational households and poor access to sanitation are common. The most impoverished Roma were thus doubly hit by the lockdown measures because of the informal and mobile economic activities that generate most of their income, as well as their substandard, overcrowded housing conditions.

The state of exclusion of the Roma is well embedded in history (Barany, 2002; Powell and Lever, 2017; Anghel, 2018) and the recent developments of the post-socialist era saw, at least in the first twenty years after 1989, a worsening of the situation of the ghettos. First, the total number of ghetto

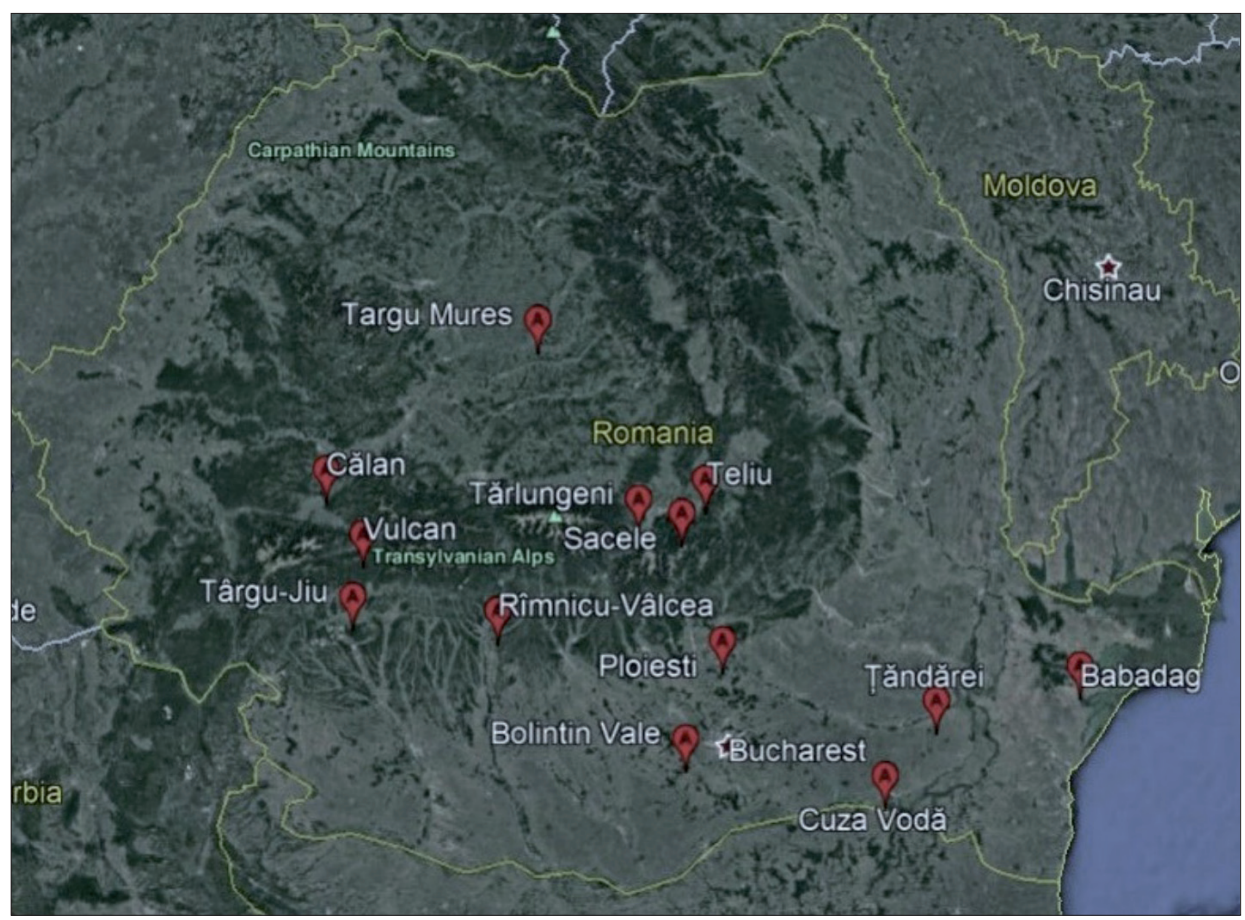

Fig. 1: Places of most intensive media-reported conflicts between segregated Roma and local police forces/ authorities during the state of emergency in Romania. Source: authors' compilation 
inhabitants, exceeding half a million or $46 \%$ of all Romanian Roma according to the SocioRoMap data (Horváth, 2017), is large in comparison to other CEE states. For example, in Slovakia, it is estimated that over 68,000 Roma live in segregated settlements, or $17 \%$ of the Roma population, while in Hungary a rough estimate of $20-26 \%$ or 134.000 Roma are presumed to live in "colony-dwellings" (Kosa, Darago, and Adany, 2009; Mušinka, 2014).

Second, the Roma ghettos in Romania are widespread and diffuse across towns and villages, suggesting that patterns of negative quarantining are potentially extensive. According to SocioRoMap, $97.6 \%$ of all Roma live in 3,490 territorial units corresponding to $27.6 \%$ of Romania's territorial units (Horváth, 2017, p. 79). Additional in-depth information was collected for 2,315 segregated communities, totalling 557,137 Roma persons out of the 1,215,846 hetero-identified Roma. For our research interest, we used indicators regarding access to potable water, number of households with running water inside their house, overcrowding, living conditions and informal sources of income that require work outside the compact group, for all 2,315 segregated communities.

Figure 2 shows that there were several layers of hardship imposed on the Roma during the lockdown. The first one was at the macro level, which referred to restrictions on travel for most Romanian migrants working abroad. According to SocioRoMap estimates, there were 284 compact groups, comprising 125,300 people in which more than $30 \%$ of the working age population worked abroad. Once the crossborder travel was restricted, all these communities were potentially affected by the reduction in foreign-based income. The Roma were particularly hard hit, since their main means of travel were cars and small vans which were easily targetted by border police. Many ended in improvised quarantining centres, some of which were criticised for their unhygienic conditions.

Second, based on SocioRoMap estimates, we compiled the income sources of the $30 \%$ most precarious segregated Roma communities. In a total of 527 compact groups with a combined population of 147,600 individuals, at least $30 \%$ of those able to work did so as daily labourers, and for this they most likely had to leave their segregated areas to find employment. Although fewer in number, there were also compact Roma groups that relied on even more precarious sources of income, such as the collection of forest fruits, the collection of recyclable materials or begging, all of which were outside their living areas. These instances show that Roma ghettos were heavily dependent on external resources and the curtailment of their daily movement had a negative impact on their livelihood.

Thirdly, the imposed quarantine has tended to increase the pressure on community resources, such as water and access to services. Self-isolation was very difficult when the source of water was located outside the home. There were 1,495 compact groups with a total population of 397,200 individuals, in which running water was available for at most $30 \%$ of households. Private bathrooms were even rarer in such communities, with 1,882 groups $(527,200$ individuals) having bathrooms in at most $30 \%$ of households (Horváth, 2017). For both these indispensable facilities in the fight against Covid-19, namely running water and private bathrooms, there was acute deprivation compared to the majority, only $49 \%$ being equipped with indoor running water and just 59\% with private bathrooms.

Fourth, Roma households were ill equipped to cope with the medical and economic consequences of the coronavirus outbreak. More than two thirds of them were at risk of poverty, almost three times higher than the national average (FRA, 2018, p. 33). Some were engaged in economic practices that required physical and social interactions or work in the informal market, which meant that they could not receive any compensation for the loss of income suffered as a result of the restrictions imposed by the state of emergency due to the current pandemic. The social protection system has poor efficiency and does not always reach those most in need. The World Bank's Report on Roma Inclusion in Romania revealed that social protection programs reduced by a mere $9 \%$ the share of Roma households living in poverty in the lower quintile (from 82 to $73 \%$ ) (World Bank, 2014, p. 135). The Guaranteed Minimum Income, the main instrument for antipoverty alleviation, has devalued over time, reaching now only

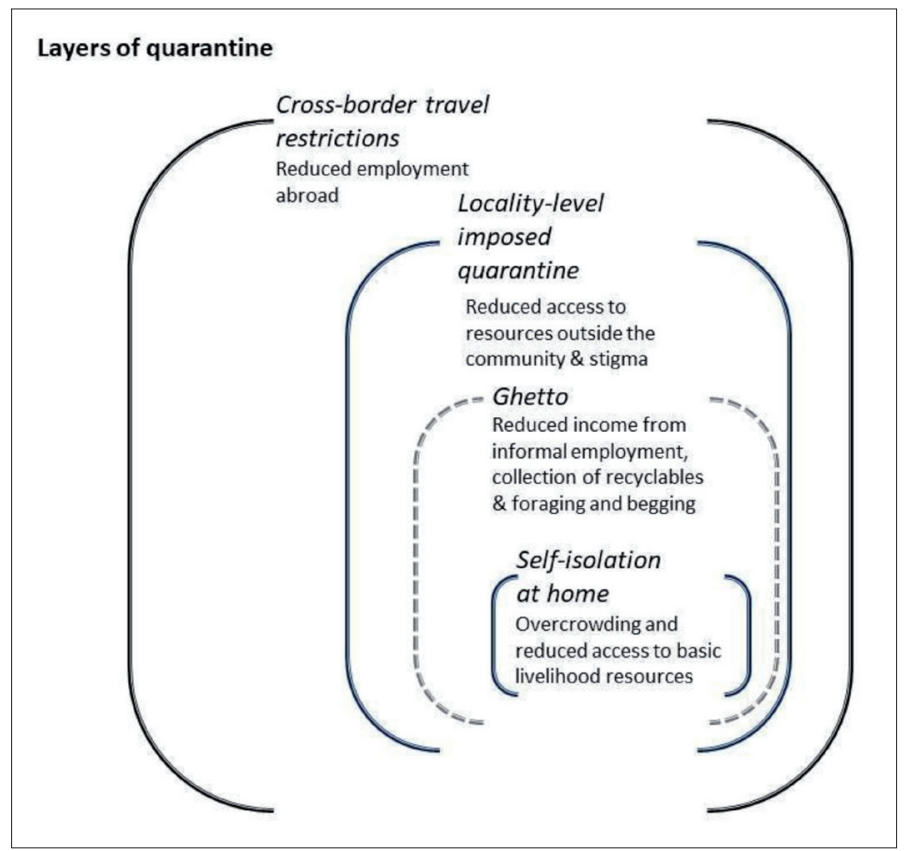

Fig. 2: The layers of quarantine and their impact on the mobility of the Roma Source: authors' conceptualisation 
one tenth of the net minimum wage at just 29 euros/person. This made the acquisition of disinfectants and masks difficult. Moreover, cash savings were absent in these communities, completely dominated by loan sharks, therefore the inhabitants were more prone to starve in times of hardship.

Recent and previous research reveals that most of the Romanian Roma from compact and segregated communities live in overcrowded or crowded households. For example, Horváth (2017) used the last Romanian census data from 2011 to show that the average number of persons per room in Roma households was 2.7, while their own research on compact communities indicated that half of the Roma lived in overcrowded households, meaning more than 4.5 persons/room, while another quarter lived in crowded households, with between 2.7 and 4.5 persons/room (Horváth, 2017, p. 104). This means that almost 75\% of the Roma live in overcrowded households which made physical distancing difficult if not impossible. Also, almost half of the families lived in just one room, while in $13 \%$ of the cases, multiple families reside in one room.

Half of the Roma from compact communities live in households that are inadequate for living, such as improvised shelters, containers, abandoned industrial facilities, former socialist workers' dormitories, or colonies (Horváth, 2017, p. 109). The very low quality of housing, linked with the disappearance of the social housing sector (Şoaită, 2017; Turcu, 2017) and with the inefficient administrative policies directed towards large housing estates, especially those with vulnerable populations (Marin and Chelcea, 2018), led to a major housing crisis for the poor, further deepened by a policy of evictions (Berescu, 2010; Lancione, 2019).

The pre-existing conditions have revealed that ghettos lacked the basic resources that would have made their inhabitants self-sufficient for more than a few days. Securing their precarious income through informal activities, which was quite common as shown above, prevented the ghetto residents from having access to the legal permissions issued by formal employers. Lacking these legal documents rendered their subsistence work illegal and thus punishable by the police. As will be shown below, the limitations on movement, abroad and internal, went beyond the formal level and acquired a whole discursive edifice activating distinct racialised tropes. The way in which the negative quarantine affected Roma ghettos was by cutting-off the vital flows, economic and social, between the ghetto and the outside world.

\subsection{Migration, sudden return, and the epidemiological outcry}

Since Romania became an EU member state in 2007, the migration of Roma towards Western Europe has been highly politicised and framed as presumably "natural nomadism" by mass media and political actors. Anthropological studies have revealed however that the motivations behind their migration are linked, as in the case of non-Roma, to the lack of better socio-economic conditions in the countries of origin and to the attempt to build a better future in the West (Cherkezova and Tomova, 2013). The Roma have adopted a circular transnational labour migration (in agriculture and construction) that helped improve their socio-economic status in their home country and to contest their symbolic subordination vis-à-vis the majority (Troc, 2012; Toma, Tesăr and Fosztó, 2014, 2018). As with many other CEE migrants, however, the pandemic signified the return of many Romanian Roma, which led to a heightening of racist and stigmatising discourses.
One of the most obvious instances of scapegoating Roma migration occurred in May 2020, when former president Traian Băsescu affirmed that "the nomad Roma, who are incapable to integrate [...] have now returned home, because isolation has been introduced throughout Europe. And if they were to remain in Europe, only they would be on the streets with the carabinieri, the police and the gendarmerie, and they would not like it, because they would be treated worse than the [treatment they] receive from our gendarmerie!" Nicolae Bacalbaşa, a former Romanian deputy, inflamed the public sphere by stating on his social media page that while "the Chinese got their virus from their bats, we'll get it from our crows" (the latter is a slur word for Roma). These kinds of public statements coming from high-level political figures reveal an ideological background for the practice of negative quarantine, eagerly backed by the media. In April 2020, while still at the outburst of Covid-19, a renowned journalist created on a television post a build-up of threatening narratives suggesting an actual Roma "invasion":

[A]lthough data on ethnic affiliations of the returnees are not available in the last 20 days [April 1-20], the daily average of entries in the country was 1,000 Romanian citizens, of which 800 are Roma... there is no discrimination, they are our compatriots, but we know very well that this area of crime is very important to understand from the perspective of entering the country [...] We are going to show you a moment when Rome is put under terror. It is about the way in which some Romanian citizens of Roma ethnicity practically placed the capital of Italy under terror (Antena $3 \mathrm{TV}$ station, as cited by Centrul de Resurse Juridice et al., 2020).

The conceptualisation of Roma migration in terms of "welfare scroungers", who do not want to work but prefer to live from illegal activities, is not novel. The permanent policing and racial targetting of Roma in Western Europe have rendered an "un/free mobility" (Yildiz and Genova, 2017) regime, in which many Roma are unable to exercise their EU citizenship because of the securitisation practices that subjects them to exceptional measures and renders them in a permanent state of deportability (De Genova, 2002) or evictability (van Baar, 2017). The effects of mobility on Roma communities are complex and multidimensional, however, and they also entail complex positive effects (Toma and Fosztó, 2018), not only through remittances, but also in terms of their human rights self-awareness and capacity to communicate. This was demonstrated by the intense communication on social media of the Roma that were quarantined in hastily improvised special quarantine centres at the beginning of the pandemic, and in which the conditions were dire. This intense communication took the form of live videos on Facebook and their extended sharing. In some cases, there were ad hoc protests by the Roma against the inadequate accommodation and substandard utilities.

The pendular migration process in which they were involved had suddenly faced several barriers, which laid bare the structure of governance that overwhelmingly affects marginalised people that live in segregated areas (Picker, 2017). For the Roma returning from Western European marginalised areas, such as campo nomadi or informal camps, plagued by similar conditions (Stasolla and Vitale, 2020), this meant entering a state of limbo, as authorities grappled with the solutions to their mobility. Also, the perspective of returning to their modest living conditions from which they had left, added to their distress. 


\subsection{Ethnicising the lockdown: how media portrayed Roma neighbourhoods}

Imposing the strict lockdown by local authorities met little to no resistance from the general population, due in part, perhaps, to pre-existing racial stereotypes. The latter were revealed by a recent survey on the perception of the Roma during the first stage of the Covid-19 pandemic that were collected by a Romanian polling institute (IRES) in June 2020. According to the poll, more than two thirds of Romanians saw the Roma as creating a bad image for Romania, while $60 \%$ thought that police violence against the Roma was justified (see Fig. 3). The same pollster revealed that when respondents were asked about the main vectors for spreading Covid-19, Roma were assigned the third position, after the diaspora and the mostly imaginary category of "the immigrants" (IRES, 2020).

As the national TV station Antena 3 claimed in a popular talk show: "The worst part of the coronavirus pandemic in Romania [was] the return of the clans that terrorised Europe". They mentioned the return of some 16,000 Roma, without providing any source of information, a failure for which they were sanctioned by the National Audio-Visual Council of Romania. The focus of much news reporting was the breaking of quarantine rules by the returning Roma. A case in point is the small town of Ţăndărei (population 12,000), where, according to police sources, 800 Roma who returned from the UK, Germany and Spain were guarded by police to remain indoors. Similarly, 900 Roma returned to the city of Babadag, a situation which was described by the national news platform Hotnews (2020), under the title: "A town quarter of 2,500, mostly Roma, has been quarantined", as follows:

People in the city quarter [where several Covid 19 cases were detected] move freely, without consideration for the limitations imposed by the military decrees. The buildings which they inhabit have multiple entries and as soon as the police officers withdraw, they re-emerge on the streets or move between their yards, as the fences separating them are in disrepair or missing.

To contain these potential rule offenders, the local police force asked for support from the national police. The description of these facts was associated with racialising observations, such as the alleged reasons for the return of the Roma from abroad was that they had apparently lost their "employment" there - a derisive term associated with petty or organised crime - and have now come back to Romania to break quarantining rules and infect the majority population. This is nothing new in the history of pandemics and, as Matache, Leaning and Bhabba (2020) aptly put it: "Racist scapegoating of outsiders in times of epidemic is a strategy with an ancient pedigree."

Less visible are the low-profile cases in which segregated areas inhabited by poor Roma were quarantined. In such cases, the areas were cordoned off from the community. This happened in a Roma ghetto in the city of Târgu Jiu, where the local media news platform gorjeanul.ro informed the reader that "The Roma from two districts of Târgu Jiu, [were] kept in quarantine at gunpoint! Police crews guarded the exit from Obreja neighbourhood" and "[outside the quarantined areas] the rest of the population was very relaxed, the streets teeming with pedestrians and shoppers".

In some cases, food and other vital supplies were offered to the quarantined ghettos to confront local significant challenges. For example, one regional media outlet, replicaonline.ro, titled at the beginning of May: "Hell on earth at Cuza Voda: People are howling for food behind fences, the authorities are overwhelmed", a cruel account of a real situation, described with a visibly dehumanising touch. Many other cases, like Vulcan, Călan, Vâlcea, etc, were only visible on social media, and pointed to the same severe food shortages and institutional abandonment.

Mainstream media were less prone to racist attacks; nevertheless, the selection of outbreak cases was far from being colour blind. Even when the Roma were not mentioned, the images were telling a racialised story. The combination of blatant racism and the ignoring of structural problems lead to an invisibilisation of the social and economic conditions under a plethora of "exotic" cases. In brief, the stress on the scandalous brushed aside the structural conditions of disadvantaged Roma neighbourhoods.

In several localities, such as Săcele, Teliu, Tărlungeni, Bărbuleşti, and Ţăndărei, major police interventions took place. A news website titled: "City hall under siege: After their return from England, the stranieri (ironic name for capped Romanian football players playing abroad) have broken the quarantining rules and terrorised the locality". In the Transylvanian village of Teliu, the Roma rioted for food, threatening the mayor to "give them food or else they

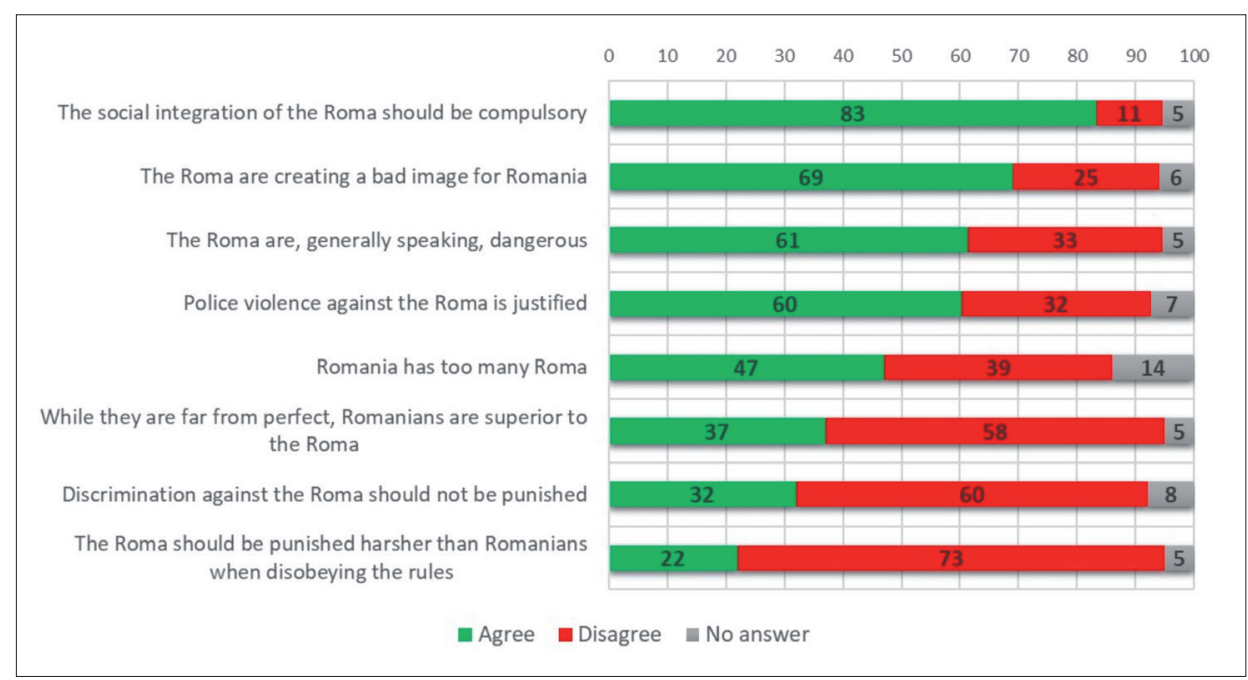

Fig. 3: Political positions of Romanian citizens towards the Roma

Source: IRES (2020) 
will cut off his throat", as reported by the Naţional news blog in April 2020. Their request for food and other necessities made local authorities claim that they felt "under siege", and did not result in major conflicts in the end, but it pointed out to the fact that the communities experienced acute hunger in the short term, and they were contemplating severe undernourishment in the long run.

Several family feasts organised by some Roma were taken as indicative of the entire group's failure to obey quarantining rules. On occasion, as the national news platform G4media stated, "violent scandals in Romainhabited quarters in Bucharest, Ploieşti and Săcele" caused the police forces to intervene. While the events themselves were based on a challenge-response mechanism, as the police were occasionally challenged by some Roma to intervene, the reactions of the public through social media revealed racist attitudes. The regime of imposition of the quarantine and the means through which it was exercised can be characterised as over-policing, sometimes with an overwhelming show of force against those who broke the rules (Ivasiuc, 2015).

In a Facebook video posted by the Romanian Police, an armada of police vehicles with wailing sirens was shown entering the town of Ţăndărei in early April to contain a Covid-19 outbreak in the Roma quarter. A similar video of an oversised intervention was broadcast at the end of March on a regional media outlet in Târgu Mureş, where police cars and unarmed soldiers patrolled in early March the Roma quarter of Valea Rece urging people to stay indoors. The national television Digi24 showed a night video of helicopter surveillance of the Rahova quarter of Bucharest, following a violent conflict with "Roma clans". Keeping the infectious Other at a distance is a regular securitisation practice, which is not efficient as a sanitary measure but is employed for its performative value.

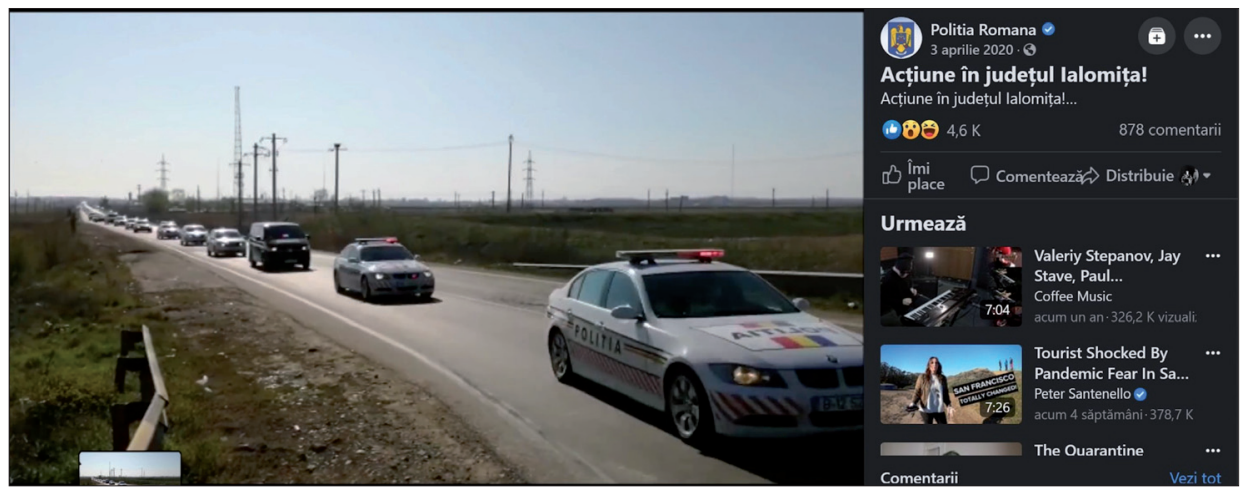

Fig. 4: A very long convoy of national police vehicles on their way to the quarantined town of Ţăndărei, labeled as "Action in Ialomita County!". Source: https://www.facebook.com/www.politiaromana.ro/videos/687997445275761/

In this tense context, a well-fed individual from the Roma-inhabited Rahova quarter of Bucharest, nicknamed "Spartacus", challenged the police to come to his place, where he was having a big party with around 40 guests and threatening that he would turn over their cars. He instantly rose to national notoriety and was portrayed as representative for an entire minority, as part of a recurring strategy of representing Roma as unruly, violent, rough and abusive scandalmongers. The episode ended with lots of gunshots in the air and with the imprisonment of five people. Soon "Spartacus" became a common noun for non-law-abiding individuals, also dubbed as bombardieri (bombardiers, i.e. boxing people), seen as the spearhead of the community transmission of the virus. The real victims, however, were two Roma neighbours who were severely beaten by the police, though innocent and definitely not part of the scandal.

The helicopters sent above Rahova to survey other possible illegal parties also marked the apex of the lockdown policies and were not just a surveillance action, but also a media stunt through which the invisible enemy was meant to become visible. This was based on the fact that Bucharest's urban ghettos of Rahova and Ferentari are the epitome of unruly, informal areas of Bucharest (Berescu, 2011; Teodorescu, 2018) with nationwide fame. The excessive use of violence was partly enabled by a temporary suspension of the Council of Europe ( $\mathrm{CoE}$ ) human rights provisions, taking advantage of Article 15, which allows signatory countries to derogate from the $\mathrm{CoE}$ convention in times of a "public emergency threatening the life of the nation." (EURACTIV, 2020a). The performative value of these interventions is shown in the fact that these police actions were not repeated after the end of the state of emergency.

\subsection{A breakdown of quarantine features as applied to the ghetto}

While the neutral, medical aim of isolation was to prevent the community transmission of Covid-19, in negative quarantine terms, the aim was to safeguard society from a major threat posed by a distinct part of it, namely the infectious Other. Antithetically, the aim of positive quarantine was to demonstrate the capacity of the "civilised" part of society to align to a common moral goal.

While regulation of movement and curfew were the major measures that supported the aim of isolation, in their negative dimension they were intended to prevent the mix with a population that was already perceived as "unmixable", a common racist stereotype. For the "positive quarantine" endorsers, the conformation to the rules was framed as a rational adaptation to the risks associated with Covid-19. From the latter standpoint, any movement of the poor in search of means of subsistence was "excessive", hence irrational. The opposition between a majority that sees itself as a settled population vs. a nomadic one, though fake, is constantly mobilised and reactivated whenever it serves the purpose to make a distinction based on the legitimacy of movement (see also van Baar, 2017).

For example, a Romanian daily, Gândul, titled one of its articles: "The Roma camps from London return to Romania", and this turned into a Facebook meme which showed a murder of crows on a fence with the title: "All flights grounded on Tăndărei airport". The 12,000-inhabitant town became prominent on the media scene even before the pandemic, due to a scandal related to child trafficking, spectacularly stormed by joint British-Romanian police 


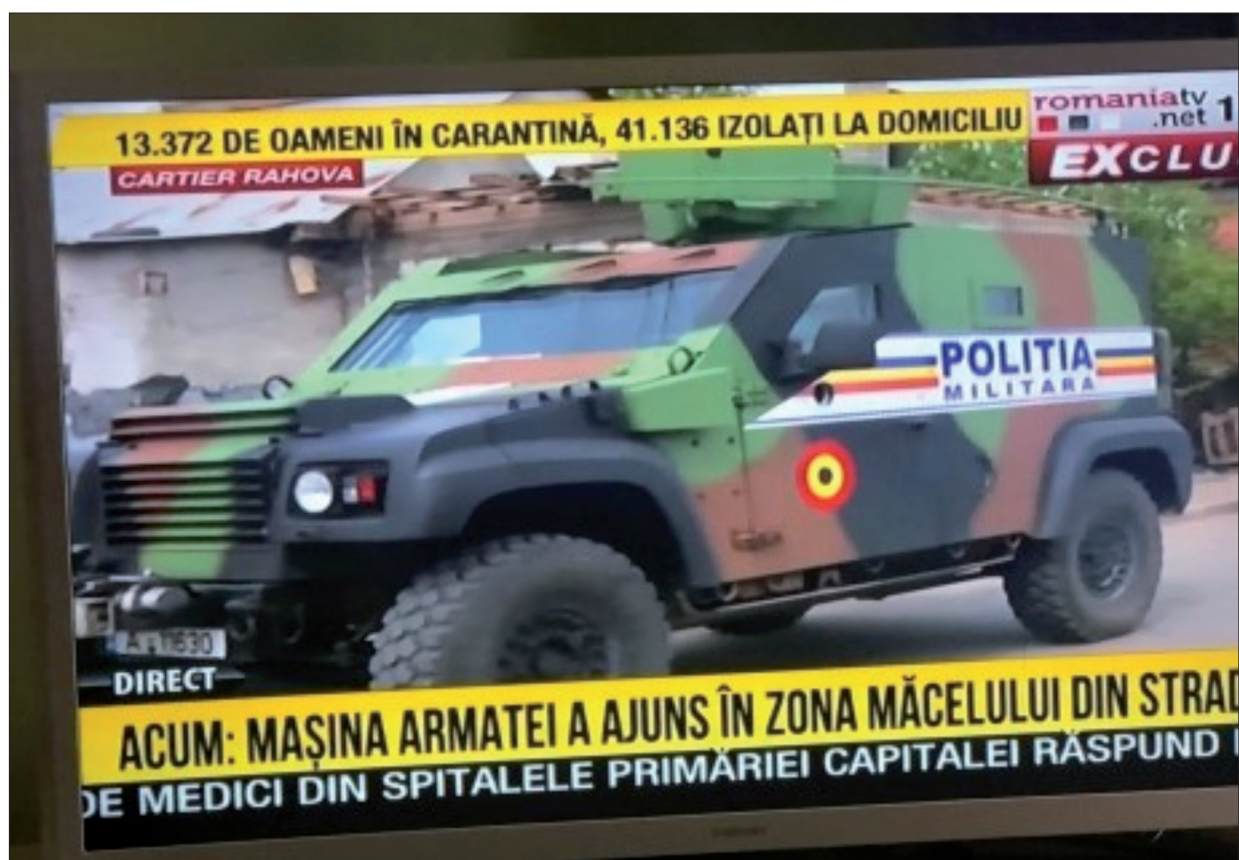

Fig. 5: Military police patrolling Rahova in Bucharest, Sector 5. The subtitle says that it arrived "in the area of the slaughter" in an article titled "Spartacus put the army on fire. Military patrol in front of his house after "the circus" ended". Source: https://www.stiripesurse.ro/spartacus-a-pus-si-armata-pe-jar-patrula-de-politie-militarapostata-la-casa-barbatului-dupa-circul-din-rahova_1455583.html

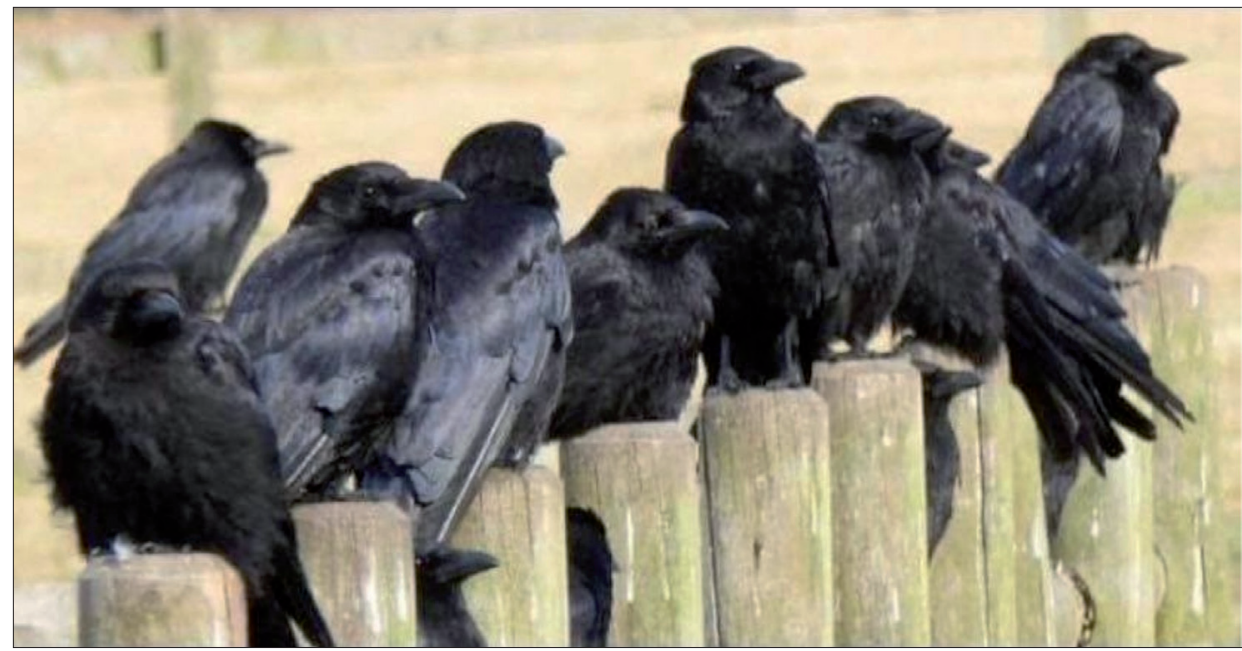

Fig. 6: Facebook meme suggesting that the quarantining of a Roma (crow)-inhabited town was like the grounding of planes on an airport. Source: https://romania.europalibera.org/a/cncd-vladimir-tismaneanu-amendat-cu-5-000-delei-pentru-postarea-despre-tandarei/30595800.html

forces that used helicopters to arrest several local leaders. After one well-known Romanian intellectual shared it on his page, it triggered a huge reaction of protest among civil society and a fine by the NCCD (Necula, 2020).

This hard line of racist remarks was briefly reversed during the asparagus harvest in Germany. Due to the sudden demand for agricultural workers to harvest the asparagus, the image of the threatening low-skilled worker returning to Romania was replaced with that of the "essential worker" saving German asparagus production, and thus became an almost heroic figure of the anti-pandemic fight.

The lack of access to goods and services was what distinguished segregated communities from the nonsegregated areas of the locality. Underequipped places had to supplant the lack of services through the enhanced mobility of their residents. With the imposition of the quarantine, any sort of vital movement became not only immoral, but illegal. The moral superiority of the middle class was based on socio-economic privilege and was epitomised by the use of digitally mediated work, while household consumption was based on delivery services (Bădoi, 2020).

This was turned into a discourse about a morally desirable form of quarantine - a positive one - which became dominant and revealed an asymmetric access to the media. The fundamental need to access physical services or manual work was diminished. While the material challenges that affected the entire society generated unequal effects across various socio-economic groups, they were more severe for the Roma ghettos.

The policies of visibility were part of a discursive device that was employed by the media to render visible processes that were elusive, such as the spreading of Covid-19. The 
images during the lockdown showed partying or congregating Roma, suggesting that the disease might easily spread from those places. This helped visualise the rationale for imposing negative quarantine. While the neutral quarantine was fed by images and messages of shared responsibility for flattening the curve of infections, the positive quarantine was a parade of virtue signalling on social media. The latter was suggested by Facebook posts and pictures championing creative home-based activities, mediated social activities and various self-restraint initiatives, all in the name of keeping the spread of the virus at bay. After the lockdown was lifted, these images were less frequently used. The discourse of positive quarantine was briefly revived, however, on the TV station Digi24 through statements of the self-proclaimed King of the Roma advising everybody, including all Roma, to respect the protection measures.

The reflection of several incidents in Roma communities in the mass media closely followed the ill-famed Roma quarters, which largely illustrated the practices of sensationalism and poorly informed reports. Although one third of the respondents from the above-mentioned IRES poll acknowledged an increase in the anti-Roma hate speech, just one in ten associated the spread of the virus with the Roma. This should be read in the particular dynamic of the popular understanding of Covid-19, one in which solid knowledge was built up very slowly and is still incomplete, while a variety of conspiracy theories gained a prominent place for various groups (Stoica and Umbreş, 2020).

\section{Conclusions}

This article engages with the idea that the quarantine imposed by the Covid-19 pandemic can be conceptualised through a threefold classification of positive, neutral, and negative quarantine. Each of these categories applies distinct but interrelated logics of quarantining for different socioeconomic groups. Since the outbreak of the pandemic, the Roma living in segregated ghettos and slum areas have experienced what we have termed negative quarantine. This had both a structural and a discursive dimension and can therefore be used as an exploratory tool for upcoming epidemiological crises. Since quarantining is not exclusively a medical act, we can only ask whether it is, in the case of the Roma, a form of moral panic. In terms of urban governance, the inability of the authorities to have a quick and decent response to the problems raised by the pandemic, indicated that the effects of negative quarantine might be not only hunger and social unrest, but a deepening of urban segregation.

By blaming the Roma for their weaker hygiene standards, the securitisation practices that have sprung in many of the poor, often informal and segregated settlements in CEE tended to invisibilise complex mechanisms of socio-economic and political exclusion and marginalisation that have historically plagued Roma settlements. Special measures of containment were enforced in several places, arguing that it is the Roma who do not respect hygiene standards and physical distance, obliterating thus the lack of access to basic utilities and the overcrowded and substandard housing conditions, which made isolation and proper hygiene nearly impossible. As reflected in the perception of the Roma during the pandemic, this might serve in future crisis-prone situations as an argument for enforcing a disciplinary policy that goes beyond the aim of medical intervention.

We have showed that Roma communities have been on the losing side of quarantining policies, in those areas with many return migrants from Western Europe. The sudden influx of Covid-19 suspects had led to exceptional measures of quarantine, with little regard for, or even total disregard for the livelihood effects on the quarantined ghetto areas. The early 2020 climate of fear was soon replaced by a climate of distrust in authorities and by the proliferation of conspiracy theories. Surprisingly, this did not include the Roma, the racist attacks stagnated, and the negative quarantine did not develop for the time being.

"Negative quarantine" is offered in this contribution as a concept to reveal diverging institutional logics of safeguarding public health during and after an epidemic. This concept problematises processes of social sorting that are activated during crisis situations, such as epidemics. Its origins are largely path-dependent, as the "infectious" communities or individuals are those that have been stigmatised and marginalised before. The implications are open ended and aggravating since they reverse the logic of protecting public health into a logic of social punishment of segregated areas. For the time being, the scapegoating of the Roma did not escalate, but the problem is still present and can worsen at any time. From a policy perspective, the quarantine can no longer be seen as a neutral, technical, and medical procedure, but needs to be considered as a complex practice with ramified implications in the governance, administration and planning of marginalised areas.

\section{Acknowledgments}

Research grant funded through the Trustees Fund, made available to the Romanian Academy and managed by the "Patrimoniu" Foundation GAR-UM-2019-XI-5.6-3. We thank Professor Istuán Horváth and the Romanian Institute for Research on National Minorities team for offering access to the SocioRoMap database.

\section{References:}

ANGHEL, I-M. (2019): 'It's in Their Blood'. The Securitization of Roma Westward Migration in Europe. Calitatea Vieţii, 30(2): 146-161.

ANGHEL, I-M. (2018): Romania's perennial 'outsiders'. From a foreign non-European minority to intra-EU displacements. An exploration of Roma's perpetual socioeconomic and symbolic exclusion. Journal of Community Positive Practices, 18(4):3-18.

ARPAGIAN, J., AITKEN, S. (2018): Without Space: The Politics of Precarity and Dispossession in Postsocialist Bucharest, Annals of the American Association of Geographers, 108(2): 445-453.

BALDACCHINO, G. (2021): Extra-territorial quarantine in pandemic times. Political Geography, 85: 102302.

BARANY, Z. (2002): The East European Gypsies: Regime Change, Marginality, and Ethnopolitics. Cambridge, Cambridge University Press.

BĂDOI, D. (2020): Munca pe platformele digitale de livrare din România. Revista Calitatea Vieţii, 31(4): 379-83.

BERESCU, C. (2010): Something on the Art of Eviction in 2000 Romania. In: Serban, A. [ed.]: Evicting the Ghost: Architectures of Survival (pp. 113-120). Bucharest, Centre for Visual Introspection.

BERESCU, C. (2011): The ghetto and the disadvantaged Housing Area Aleea Livezilor. In: Botonogu, F. [ed.]: Hidden Communities: Ferentari (38-57). Bucharest, Expert. 
BERTA, P. (2020): Ethnicizing a Pandemic: COVID-19, Culture Blaming, and Romanian Roma. Society for Romanian Studies Newsletter, 42(1): 1-7.

BULGARIAN INSTITUTE FOR LEGAL INITIATIVES (2020): The state of emergency in the large minority neighbourhoods, March 13-May 13, 2020. Sofia, Bulgarian Institute for Legal Initiatives.

CACE, S., PREOTEASA, A. M., TOMESCU, C., STĂNESCU, S. M. (2010): Legal şi egal pe piaţa muncii pentru comunităţile de romi. Diagnoza factorilor care influențează nivelul de ocupare la populaţia de romi din România. Bucharest, Expert.

CENTRUL DE RESURSE JURIDICE (2020): Minoritatea romă: ţap ispăsiitor în vremea pandemiei. Bucharest, Cluj-Napoca, Centrul de Resurse Juridice.

CHERKEZOVA, S., TOMOVA, I. (2013): An Option of Last Resort? Migration of Roma and Non-Roma from CEE countries. Bratislava, UNDP.

COSTACHE, I. (2020): Until we are able to gas them like the Nazis, the Roma will infect the nation:" Roma and the ethnicization of COVID-19 in Romania [online]. [cit. 01.09. 2020]. Available at: https://www.dor.ro/roma-andthe-ethnicization-of-covid-19-in-romania/

CREŢAN, R., LIGHT, D. (2020): COVID-19 in Romania: transnational labour, geopolitics, and the Roma 'outsiders'. Eurasian Geography and Economics, 61(4-5): 559-571.

DE GENOVA, N. (2002): Migrant 'Illegality' and Deportability in Everyday Life. Annual Review of Anthropology, 31: 419-447.

EURACTIV (2020a): Coronavirus derogations from human rights send wrong signal, say MEPs [online]. [cit. 14.08.2020]. Available at: https://www.euractiv.com/section/ justice-home-affairs/news/coronavirus-derogations-fromhuman-rights-send-wrong-signal-say-meps/

EURACTIV (2020b): Bulgarian authorities struggle to enforce containment with Roma population [online]. [cit. 14.08.2020]. Available at: https://www.euractiv.com/ section/languages-culture/news/bulgarian-authoritiesstruggle-to-enforce-containment-with-roma-population/

FRA (2018): A persisting concern: anti-Gypsism as a barrier to Roma inclusion. Luxembourg, European Union Agency for Fundamental Rights.

GABRIZOVA, Z. (2020): Slovakia to merge two stages as the country starts reopening [online]. [cit. 04.05.2020]. Available at: https://www.euractiv.com/section/healthconsumers/short news/slovakia-covid-19-update/

GOLDSTEIN, D. (2010): Toward a Critical Anthropology of Security. Current Anthropology, 51(4): 487-517.

HEPWORTH, K. (2012): Abject citizens: Italian 'Nomad Emergencies' and the deportability of Romanian Roma. Citizenship Studies, 16(3-4): 431-449.

HORVÁTH, I. (2017): Raport de cercetare - SocioRoMap. O cartografiere a comunităţilor de romi din România. Cluj-Napoca, Institutul pentru Studierea Problemelor Minorităţilor Naţionale.

HOTNEWS (2020): Babadag: Cartier cu 2.500 de locuitori, majoritatea de etnie romă, pus în carantină - Coronavirus [online]. [cit. 18.04.2020]. Available at: https://www. hotnews.ro/stiri-coronavirus-23872167-babadag-cartier-2500-locuitori-majoritatea-etnie-roma-pus-carantina.htm
IRES (2020): Percepția asupra romilor în timpul pandemiei de Covid-19. Bucharest, Romanian Institute for Evaluation and Strategy.

IVASIUC, A. (2015): `Segregation is Expensive`: Subverting Neoliberal Arguments in the Context of Post-Socialist Migration of the Roma to Italy? In: Troc, G., Iancu, B. [eds.]: Moduri de apropiere şi rezistenţă socială. Lucrările celei de-a XI-a conferinţe anuale a societăţii de antropologie socială şi culturală Cluj 21-22 noiembrie 2014. Bucharest, Tritonic.

KOSA, K., DARAGO, L., ADANY, R. (2009): Environmental survey of segregated habitats of Roma in Hungary: a way to be empowering and reliable in minority research. European Journal of Public Health, 21(4): 463-468.

KRASIMIROV, A., TSOLOVA, T. (2020): Bulgaria's Roma say some coronavirus measures are discriminatory. Reuters [online]. [cit. 05.05.2020]. Available at: https://www. reuters.com/article/us-health-coronavirus-bulgariaroma-idUSKBN21B355

LANCIONE, M. (2019): The politics of embodied urban precarity: Roma people and the fight for housing in Bucharest, Romania. Geoforum, 101: 182-191.

MÁLOVICS, G., CREŢAN, R., MÉREINÉ, B., TÓTH, B. (2019): Urban Roma, segregation and place attachment in Szeged, Hungary. Area, 51: 72-83.

MARIN, V., CHELCEA, L. (2018): The Many (Still) Functional Housing Estates of Bucharest, Romania: A Viable Housing Provider in Europe's Densest Capital City: Poverty, Ethnic Segregation and Policy Challenges. In: Hess, D. B., Tammaru, T., van Ham, M. [eds.]: Housing Estates in Europe: Poverty, Ethnic Segregation and Policy Challenges (pp. 167-190). Cham, Springer.

MATACHE, M., LEANING, J. BHABHA, J. (2020): The shameful resurgence of violent scapegoating in a time of crisis. Racist scapegoating of outsiders in times of epidemic is a strategy with an ancient pedigree [online]. [cit. 05.05.2020]. Available at: https://www. opendemocracy.net/en/can-europe-make-it/shamefulresurgence-violent-scapegoating-time-crisis/

MESSING, V. (2014): Methodological puzzles of surveying Roma/Gypsy populations. Ethnicities, 14(6): 811-829.

MUŠINKA, A. et al. (2020): Roma in Slovakia. Atlas of Roma Communities in Slovakia [online]. [cit. 05.05.2020]. Available at: https://www.rcc.int/romaintegration2020/ romadecadefold/documents/2.\%20isc\%20meetings/25\%20 25th\%20Meeting $\% 20$ of $\% 20$ the $\% 20$ ISC_September $\% 20$ 2013\%20(Montenegro)/Presentations/Atlas\%20of\%20 Roma\%20communities\%20in\%20Slovakia.pdf

NECULA, C. (2020): Vladimir Tismăneanu: un rasist chiulangiu. Cum a ajuns un profesor român din SUA să posteze fotografii cu „ciorile de la Ţăndărei” [online]. [cit. 11.04.2020]. Available at: https://www.libertatea.ro/ opinii/vladimir-tismaneanu-un-rasist-chiulangiu-ciorilede-la-tandarei-2950585

PICKER, G. (2017): Governance and the Segregation of Romani People in Urban Europe. London and New York, Routledge.

POWELL, R., LEVER, J. (2017): Europe's Perennial 'Outsiders': A Processual Approach to Roma Stigmatization and Ghettoization. Current Sociology, 65(5): 680-99. 
ROMLINK (2021). Official Facebook page [online]. [cit. 11.03.2021]. Available at: https://www.facebook.com/ groups/RomLink

SARDELIĆ, J. (2017): The position and agency of the 'irregularized': Romani migrants as European semicitizens" Politics, 37(3): 332-346.

SIMPSON, M. (2021): For a prefigurative pandemic politics: Disrupting the racial colonial quarantine. Political Geography, 84: 102274.

STOICA, C. A., UMBREŞ, R. (2020): Suspicious minds in times of crisis: determinants of Romanians' beliefs in COVID-19 conspiracy theories. European Societies, 21(1): S246-S261.

ŞOAITĂ, A. M. (2017): The changing nature of outright home ownership in Romania: housing wealth and housing inequality. In: Dewilde, C., Ronald, R. [eds.]: Housing Wealth and Welfare (pp. 236-257). Cheltenham.

STASOLLA, C., VITALE, T. (2020): \#IStayCamp. Health Conditions, Food Deprivation and Solidarity Problems in the First Days of Lockdown in the Roma Villages of Rome [online]. [cit. 28.04.2020]. Available at: https:// www.metropolitiques.eu/IStayCamp-Health-ConditionsFood-Deprivation-and-Solidarity-Problems-in-the.html

SURDU, M. (2016): Those Who Count. Expert Practices of Roma Classification. Budapest, Central European University Press.

TEODORESCU, D. (2018): The modern mahala: making and living in Romania's postsocialist slum. Eurasian Geography and Economics, 59(3-4): 436-461.

TEODORESCU, D. (2019): Racialised postsocialist governance in Romania's urban margins: Housing and local policymaking in Ferentari, Bucharest. City: Analysis of Urban Change, Theory, Action, 23(6): 714-731.

TOMA, Ş., TESĂR, C., FOSZTÓ, L. (2014): The immigration of Romanian Roma to Western Europe: Causes, effects, and future engagement strategies. Cluj-Napoca, Romanian Institute for Research on National Minorities.

TOMA, Ș., FOSZTÓ, L. (2018): Returnees and their neighbours: Migration of the Romanian Roma, networks, social distance, and local development. Szociológiai Szemle, 28(4): 37-60.

TOMA, Ş., TESĂR, C., FOSZTÓ, L. (2018): Romanian Roma at home. Mobility patterns, migration experiences, networks, and remittances. In: Matras, Y., Leggio, D.V. [eds.]: Open Borders, Unlocked Cultures. Romanian Roma Migrants in Western Europe (pp. 57-82). London and New York, Routledge.
TROC, G. (2012): Transnational migration and Roma self-identity: Two case studies. Studia Universitatis BabesBolyai - Sociologia, 57(2): 77-100.

TUDOR, M. (2020): The European Union is failing its largest ethnic minority in times of Coronavirus crisis. The Brussels Times [online]. Available at: https:// www.brusselstimes.com/opinion/103370/the-europeanunion-is-failing-its-largest-ethnic-minority-in-times-ofcoronavirus-crisis/

TURCU, C. (2017): Mind the Poorest: Social Housing Provision in Post-crisis Romania. Critical Housing Analysis, 4(2): 54-66.

VAN BAAR, H. (2014): The Centripetal Dimension of the EU's External Border Regime. Etnofoor, 26(2): 87-93.

VAN BAAR, H. (2017): Evictability and the Biopolitical Bordering of Europe. Antipode, 49(1): 212-230.

VAN BAAR, H., IVASIUC, A., KREIDE, R. (2019): The Securitization of the Roma in Europe. Cham, Palgrave Macmillan.

VINCZE, E., PETROVICI, N., RAŢ, C., PICKER, G. (2019): Racialized Labour in Romania. Spaces of Marginality at the Periphery of Global Capitalism. London and New York, Palgrave Macmillan.

VIROSTKOVA, L. (2020): Slovak army deployed to quarantine Roma settlements. EUOBSERVER 2020 [online]. [cit. 14.08.2020]. Available at: https:// euobserver.com/

VRĂBIESCU, I. (2020): Deportation, smart borders and mobile citizens: using digital methods and traditional police activities to deport EU citizens. Journal of Ethnic and Migration Studies, 1-18.

WACQUANT, L. (2012): A Janus-Faced Institution of Ethnoracial Closure: A Sociological Specification of the Ghetto. In: Hutchinskon, R., Haynes, B. D. [eds.]: The ghetto: contemporary global issues and controversies (pp. 1-31). Boulder, Westview Press.

WORLD BANK (2014): Diagnostics and Policy Advice for Supporting Roma Inclusion in Romania. Washington, The International Bank for Reconstruction and Development.

YILDIZ, C, DE GENOVA, N. (2017): Un/Free mobility: Roma migrants in the European Union. Social Identities, 24(4): 425-441.

\section{Please cite this article as:}

BERESCU, C., ALEXANDRESCU, F., ANGHEL, I. M. (2021): Vulnerable Roma communities in times of the Covid-19 negative quarantine. Moravian Geographical Reports, 29(2): 125-136. doi: https://doi.org/10.2478/mgr-2021-0011 